\title{
Erratum to: Treatment and outcome of children with cerebral cavernomas: a survey on 32 patients
}

\author{
Alessandro Consales • Gianluca Piatelli • Marcello Ravegnani • \\ Marco Pavanello - Pasquale Striano - Maria Luisa Zoli - Valeria Capra • \\ Andrea Rossi · Maria Luisa Garrè • Maria Grazia Calevo $\cdot$ Armando Cama
}

Published online: 24 November 2009

(C) Springer-Verlag 2009

\section{Erratum to: Neurol Sci}

\section{DOI 10.1007/s10072-009-0157-0}

In two consecutive sentences of the "Discussion" section, due to a typing error, some numbers in square brackets do not correspond to the references listed in the "References" section.

The correct sentences (i.e. reporting the correct numbers in square brackets corresponding to the references) are the following:

The online version of the original article can be found under doi:10.1007/s10072-009-0157-0.

A. Consales - G. Piatelli · M. Ravegnani - M. Pavanello .

V. Capra · A. Cama $(\bowtie)$

Department of Neurosurgery,

Gaslini Children's Hospital, Genoa, Italy

e-mail: nchigg@libero.it

P. Striano

Department of Muscular and Neurodegenerative Diseases,

Gaslini Children's Hospital, Genoa, Italy

\section{L. Zoli}

Department of Assistance for the Disabled,

National Health Service, Genoa, Italy

\section{A. Rossi}

Department of Neuroradiology,

Gaslini Children's Hospital, Genoa, Italy

M. L. Garrè

Department of Hemato-Oncology,

Gaslini Children's Hospital, Genoa, Italy

M. G. Calevo

Department of Epidemiology and Biostatistics,

Gaslini Children's Hospital, Genoa, Italy
"Several hypotheses have been put forward to explain their occurrence, including the effect of vessel wall necrosis and changes related to radiation therapy [39, 40], the ionizing effect of radiation energy generating vascular and connective tissue changes in the stroma [41], or the detection of a radiographically occult cavernoma only after radiotherapy [42]. Nimjee et al. [43] described 76 de novo CCs after radiation treatment”. 